
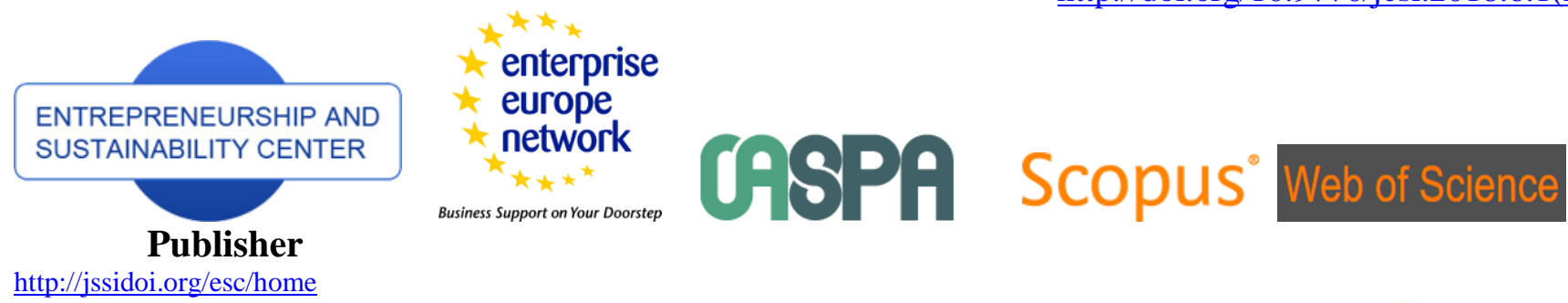

$\underline{\mathrm{http}: / / \text { jssidoi.org/esc/home }}$

Clarivate
Analytics

\title{
THE IMPACT OF OUTSOURCING IMPLEMENTATION ON SERVICE COMPANIES
}

\author{
Rima Zitkiene', Ugne Dude² \\ ${ }^{1,2}$ Mykolas Romeris university, Ateities str. 20, Vilnius, Lithuania \\ E-mails:1 rizit3@mruni.eu; ${ }^{2}$ ugne@mruni.eu
}

Received 15 March 2018; accepted 7 July 2018; published 30 September 2018

\begin{abstract}
Outsourcing, as a managerial phenomenon, is gaining importance and attention among both scientists and entrepreneurs. Despite an increasing outsourcing practice among business units, the nature of factors affecting growth of the use of outsourcing on service companies have not received adequate attention in the scientific literature. The aim of paper is to provide in-depth analysis of factor affecting the spread of outsourcing practice among service companies. A comprehensive review of the literature was conducted in the fields of services, to achieve a thorough understanding of the issues involved, and identify the crucial factors affecting the use outsourcing in service companies. Literature analysis shows that spread of outsourcing is affected by external and internal factors. Most important internal factors affecting growth of outsourcing use in service companies are strategic and economic factors.
\end{abstract}

Keywords: outsourcing; service companies; services; service management; business management; business

Reference to this paper should be made as follows: Zitkiene, R. Dude, U. 2018. The impact of outsourcing implementation on service companies, Enterpreneurship and Sustainability Issues 6(1): 342-355. http://doi.org/10.9770/jesi.2018.6.1(21)

JEL Classifications: M11, M16, M19, L14, L22, L24, L26, L80

\section{Introduction}

An examination of the activities of modern organisations shows a visible transformation of business when new business organisation models and methods are applied. In a dynamic and competitive international market, entrepreneurs are constantly looking for ways to save money, improve the quality of products and services, and increase the efficiency of their business in order to keep business and to compete successfully. Historically, companies were vertically integrated organisations seeking to control both supply and distribution channels. Products were made from raw materials and transported to own retail stores (Gerbl, McIvor, Humphreys 2009). Gradually companies began to separate business processes and outsource them to other companies or countries. According to Fuschi, Tvaronavičienè (2016), in a network structure, a central core leader operates the main strategic business and outsources the functional work, such as manufacturing, marketing and distribution. This decreases control but typically increases cost effectiveness. Pauceanu (2016) claims that innovation is a critical weapon for entrepreneurs attempting to find new opportunities of producing better goods or services. Scientific 
The International Journal

ENTREPRENEURSHIP AND SUSTAINABILITY ISSUES

ISSN 2345-0282 (online) http://jssidoi.org/jesi/

2018 Volume 6 Number 1 (September)

http://doi.org/10.9770/jesi.2018.6.1(21)

studies show that the service sector is dynamic, and that innovation encourages changes in companies, these changes being increasingly linked to outsourcing. Researchers of the manufacturing and supply chain argue that outsourcing evolved from a make-or-buy decision. Service operations management researchers tend to consider outsourcing as a new revolutionary trend (Busi, McIvor, 2008).

Due to advancement of information and communication technologies and liberalisation of international trade, outsourcing of services has started to expand rapidly including more and more activities (UNCTAD, 2004). According to Alajaasko (2006), outsourcing is one of the reasons for the growth of the service sector and increasing demand for services. Based on the overview of multi-year UNCTAD Expert Meeting on Trade, Services and Development held in Geneva in 2017, between 1980 and 2015 the share of services in GDP increased for all categories of countries: from 61 to $76 \%$ in developed economies and from 42 to $55 \%$ in developing economies. Outsourcing is a business paradigm in which an organisation transfers part of its business processes to a service provider. The structure of outsourcing is very complex since it covers a wide range of activities and functions that cause administrative and managerial dilemmas (Yi, Chen, Guo, 2016).

With increasing practical application of outsourcing, this phenomenon started to attract the interest of many researchers. Studies of different researchers all over the world (Aubert et al. 1996, Bumberg 1998, Ghodeswar, Vaidyanath 2008, Gomez J. F. et al. 2009, Kishore et al. 2003, Koszewska 2004, Choi, Beladi 2012, Lankford, Parsa 1999, Franchesi et al. 2003, Kremic et al. 2006) show that companies tend to outsource increasingly more often.

Due to changes and development of outsourcing, scientific literature employs various scientific theories, which aim at explaining the outsourcing phenomenon and the factors that determine its development. Scientific theories provide the basis for the analysis of outsourcing development factors. However, in the course of the research, it has been observed that when outsourcing is changing, i.e. as it expands, the expectations of companies and factors that determine the use of outsourcing change as well. At first, outsourcing was only expected to help minimise the costs and compensate for temporary workforce shortage. However, in the process of globalisation, manufacturing and service companies are increasingly expanding their activities in order to stay in the market, thus providing not only basic but also additional services. The researchers point to various factors that determine the development of business activities, however, their main focus is mainly on manufacturing. Nevertheless, the specifics and development of the service sector promotes research in this sector and the pursuit of a unified approach towards the factors affecting an increased use of outsourcing in service companies.

The aim of this article is to reveal theoretical background and factors affecting an increased use of outsourcing in service companies.

The methods of the research include systematic and comparative analysis of the scientific literature gathered in Web Of Science, Taylor \& Francis Online, Science Direct, Emerald Management eJournals Collection, SAGE data bases.

The paper proceeds as follows. A brief overview of theories concerning outsourcing and its groups is provided first to underline dominant theories. The next section of the article provides a theoretical context of existing literature of factors affecting outsourcing in different service companies operating in different service fields. Finally, an in-depth analysis is provided of the factors affecting the spread of outsourcing practice among service companies.

\section{Theoretical basics on outsourcing}




\section{The International Journal}

ENTREPRENEURSHIP AND SUSTAINABILITY ISSUES

ISSN 2345-0282 (online) http://jssidoi.org/jesi/

2018 Volume 6 Number 1 (September)

http://doi.org/10.9770/jesi.2018.6.1(21)

According to Busi, McIvor (2008), it is universally accepted that any phenomenon may be explained by various theoretical assumptions, based on relevant methods. Most scientific theories are used to express the attitudes of scientists towards the nature of the activities and functions of companies, as well as help them manage those processes in the right way (Vaxevanou, Konstantopoulos, 2015). The phenomenon of outsourcing is grounded in many scientific theories, which causes considerable confusion among scientists. Some of them are complementary, while others are contradictory (Perunovic, Pedersen, 2007).

In order to highlight the theories that underlie outsourcing of services, the classical and contemporary scientific theories of economics, management and service science were analysed. As mentioned before, the majority of authors focus on outsourcing in manufacturing and service companies. Dibbern et al. (2004) distinguish the following theories as the most important in the context of outsourcing: transaction cost theory (Coase 1937, Williamson 1975, 1981, 1985), resource-based view theory (Barney 1986, 1989, 1991), agency theory (Eisenhardt 1989, Jensen, Meckling 1976), social exchange theory (Blau 1964, Emerson 1972, Homans 1961), resource dependency theory (Pfeffer and Salanick 1978, Pfeffer 1984), strategic management theories: five forcers model (Porter, 1985) and adaptive cycle process model (Miles, Snow 1980), innovation diffusion theory (Roger 1962), power and politics theory (Pfeffer 1981, 1982), relationship theory (Klepper 1995, Kern 1997), game theory (Nash 1953, Kreps et al. 1982, Spence 1976, Fudenberg and Tirole 1990).

Likewise, the abovementioned authors, Gottschalk, Solli-Saether (2006) distinguished classical theories such as neoclassical economic theory (Thorstein, 1900) and transaction cost theory, however, they also draw emphasis to the fact that trade, competencies and relationships are very important in a company, thus emphasising such theories as contract theory (Arrov, 1960), alliance theory (Lévi-Strauss, 1949), relationship exchange theory (Morgan, Hunt, 1994).

Busi and McIvor (2008) distinguished ten scientific theories which, according to the authors, most often explain the outsourcing phenomenon: transaction cost theory (Coase, 1937, Williamson, 1975, 1985), resource-based view theory (Penrose, 1959, Richardson, 1972), core competency theory (Prahalad, Hamel, 1990), evolutionary economics (Nelson, Winter, 1982; Mahnke, 2001), principal agent theory (Ross, 1973, Jensen, Meckling, 1976), vertical integration (Bain, 1968; Grossman, Hart, 1986), strategic management (Quinn, Hillmer, 1968), relationship market/view (Berry, 1983; Sommer, 2003), industrial economics (Porter, 1980), strategic alignment theory (Henderson, Venkatraman, 1990). Based on research of the authors, it should be noted that not only costs, but also company integration and strategic solutions are important for outsourcing development.

Based on Vaxevanou, Konstantopoulos, (2015), it may be argued that besides economic theory, cost theory and competency theory, researchers also referred to evolutionary economics theory (Nelson, Winter, 1982; Mahnke, 2001), relational view theory (Dyer, Singh, 1998), knowledge-based view theory (), economy of information theory (Stigler, 1961, Spence, 1973).

The views of different authors indicate that the achievements of various fields of science are used to assess the spread of outsourcing in companies, however, it is difficult to establish principles for the division of theoretical concepts. The growth of technological innovations encourages companies to expand the boundaries of activity and seek new business methods. Therefore, the article takes into account the theories and models that reveal the key areas of the company's decision to use outsourcing and allow identifying factors that determine the use of outsourcing. According to the authors of the article, three main groups of theoretical concepts may be distinguished: I - oriented towards improvement of company indicators and cost reduction; II - towards internal processes of a company, whilst managing resources, introducing innovation, increasing the competitive advantage between the companies operating in the same business and III - towards improvement of mutual relations with 
existing partners and search for new ones, expanding cooperation and making decisions related to integration and merger with other companies (see Fig.1).

Although neoclassical economic theory is criticised for its inability to explain modern business operations, Gottschalk and Solli-Sæther (2005) have shown that neoclassical economic theory can be used to explain the success factors in the process of outsourcing. It should be noted that Transaction Cost Theory (TCE) is most widely used theory, and this theory as well as Resource-Based View (RBV) are indicated as the most significant theories for explaining the phenomenon of outsourcing.

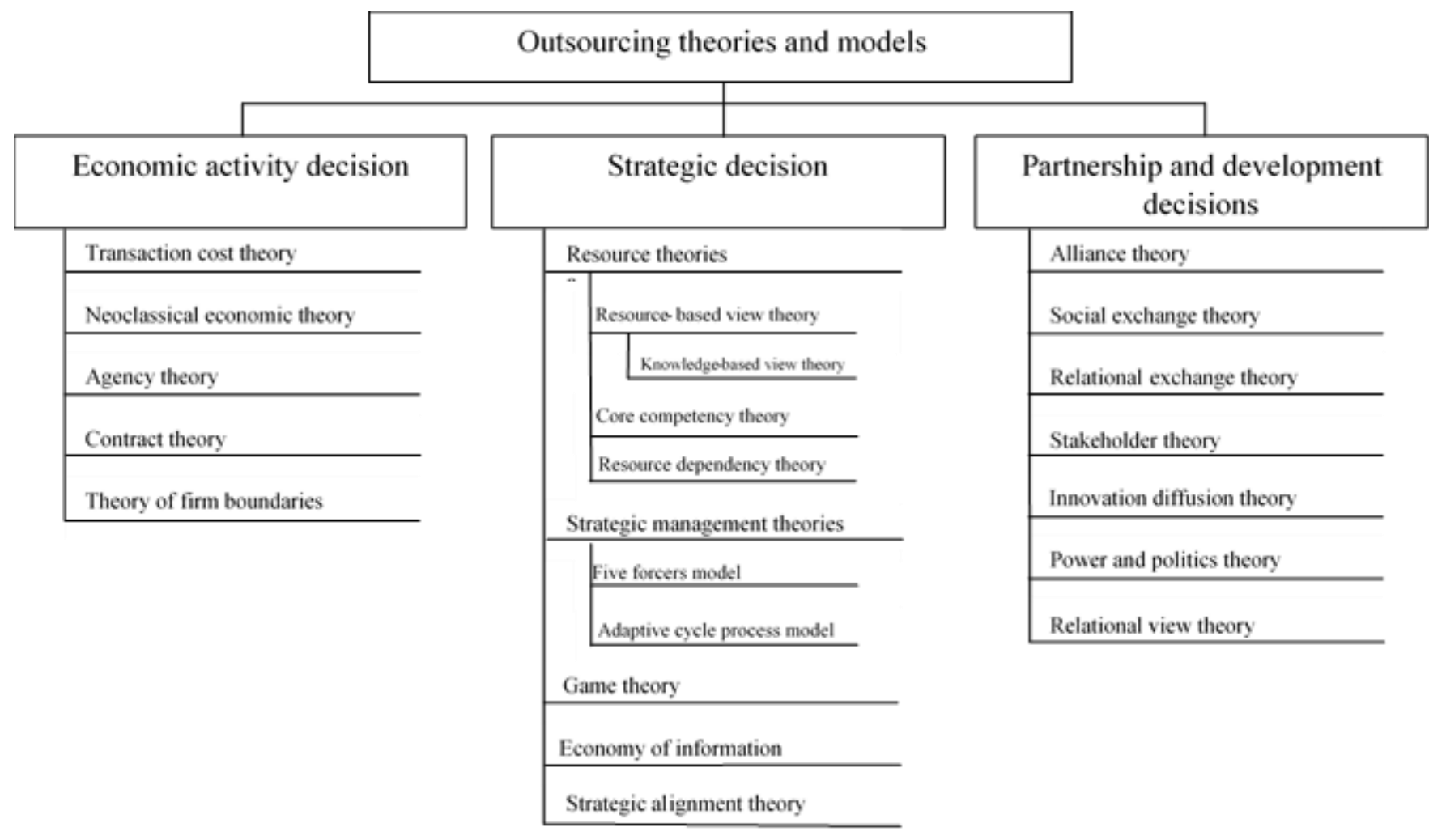

Fig. 1 Theoretical concepts of outsourcing Source: authors

Both theoretic and practical studies focus on the topic of strategic management of companies. The figure shows that a broad spectrum of theories and models is associated with strategic decisions. Knowledge-based view theory discloses how knowledge is shared and what relationship is maintained with service providers in the process of outsourcing management. Core competency theory (Prahalad, Hamel, 1990) has evolved from resource-based view theory and reveals which key competencies and skills of an organisation it manages. According to Prahald and Hamel (1990), collective knowledge management and outsourcer competencies are key factors determining the success of outsourcing contract. Porter's (1985) five forcers model is beneficial for evaluation of outsourcing in companies providing services; adaptive cycle process model (Miles, Snow 1980), which reveals cyclic renewal of institutions, is also widely used.

Many researchers used game theory in their research (Nash 1953, Kreps et al., 1982, Spence 1976, Fudenberg and Tirole, 1990) to explain the strategic behaviour of players or participants (e.g. companies) in a particular situation where everyone works under the same conditions and seek to maximise their profits rationally and reasonably and 
The International Journal

ENTREPRENEURSHIP AND SUSTAINABILITY ISSUES

ISSN 2345-0282 (online) http://jssidoi.org/jesi/

2018 Volume 6 Number 1 (September)

http://doi.org/10.9770/jesi.2018.6.1(21)

predict the actions of another player. Spence (1973), Stigler (1961) presented a model on the basis of economy of information theory, which sought to determine the scope and reliability of available information and how this information affects decision-making in an organization.

The third group theories focus on collaboration relations, relationships and development of companies that implement outsourcing. Agency theory presented by Jensen and Meckling (1976) evolved from assessment of the relationship between organisation's management and all stakeholders (agents) to the assessment of relationships between different organisations. The theory is used to analyse the stage of preparation when the organisation discusses all potential providers of outsources and decides which relationships to develop.

McIvor (2005) claims that Dyer, Singh's (1998) relational view theory may be used to explain how companies can gain and maintain competitive advantage in collaboration with other organisations. This theory is used for the studies of transitional period relationship management and is the only one that can be applied at all stages of the outsourcing process. According to McIvor (2005), relational theory provides explanations on how companies can gain and maintain a competitive advantage in their relationships with other organisations. Later studies by other researchers such as Yahnhong (2011), Saka, Vlacha, Nasiopoulos (2014) revealed that in order to develop a competitive advantage based on technology, the benefits of outsourcing are to be determined by the quality of the relationship at the time of concluding the contract and monitoring of the development of relationships between the contracting parties.

Klepper (1995), Kern (1997) argue that relationship theory helps in making an alliance and addressing the issues related to partnerships, competitive advantage, supply chain management, or supplier-buyer relationships.

According to Tushman's (1977) power and politics theory, which was used as a theoretical basis by Pfeffer (1981, 1982), Lacity and Hirschheim (1993), companies feel political power from a variety of institutions that control resources: access to information (for example, on the organization's activities, perks, etc.), which is why it affects decisions in outsourcings services.

Roger's (1962) innovation diffusion theory is considered one of the oldest social science theories. The basic principle of the theory is that during the process the focus is on target population groups and the factors that affect their decision-making. Therefore, this theory has been successfully applied in many areas, including communications, agriculture, science theories, public health, criminal law, social work and marketing.

\section{Factors influencing implementation of outsourcing}

Transformation in the global market is ongoing, therefore, companies reallocate resources by redirecting them to key operating sources in order to improve the quality of their business and gain advantage over competitors. According to Mickevičienè (2010), organisations apply different methods of management in solving the problem of the theory-practice relationship and in order to achieve the best results. Along with the traditional ways of organising business, new operational strategies are being developed to separate functions and, in some cases, outsource them to service providers specialising in the field. Changes related to crises and economic reforms were influential in local as well as international areas. Many countries moved their activities to other regions of the world. According to Kedia, Mukherjee (2009), some countries, such as India, Brazil, Russia, Hungary, Ireland and others have opened their markets. These countries have huge human capital resources which may be "lent". What is more, the authors emphasised that the development of outsourcing is influenced by globalisation, technological advancement, competition, economic reforms. 
The International Journal

ENTREPRENEURSHIP AND SUSTAINABILITY ISSUES

ISSN 2345-0282 (online) http://jssidoi.org/jesi/

2018 Volume 6 Number 1 (September)

http://doi.org/10.9770/jesi.2018.6.1(21)

Zhu et al (2001) claim that the need for outsourcing depends on four major changes taking place in a competitive market environment: continuous technological advancement, increasing risk and search for flexibility, focusing on company's specialisation, and globalisation. The development of information and communication in recent decades has had a great significance for the development of outsourcing. It has created opportunities for manufacturing and use of services in different locations, and has enabled the development of trade of services, as well as outsourcing (UNCTAD, 2004).

The scale of the spread of information and the changing economic structure encouraged the development of global and integrated operations. Multinational organisations have started to replace local companies. The advancement of information technologies changed business environment and companies aiming at cost reduction and increased availability of their services have started to invest in virtual offices at strategically convenient territories. Furthermore, trade liberalisation, reduction of international direct investment barriers and regulations in such fields as financial services, transportation, telecommunication and professional services between developed and developing countries reduced the costs of transportation and telecommunication and encouraged the growth of international network outsourcing. Increased competition and the fact that competitors use outsourcing to make their activities more effective stimulate the companies to practice outsourcing to minimise their costs, improve product quality and enable the company to effectively compete in an international market (Bahrami, 2009).

Scholars Lahiri, Kedia (2011) distinguished independent factors that influence the implementation of outsourcing. The above-mentioned factors are external: the lack of specialists with specific skills due to state policy, increasing costs related to business execution, development of information and communication technologies, increasingly intensive competition. The research conducted by Borodako et al., (2015) revealed the factors and their determinants that depend not on the organisation but rather on political, legal, economic, social and cultural environment.

Although the influence of service sector on economics is growing, research on outsourcing of different services is scarce. It was noted that a great part of scientific works iare dedicated to the analysis of outsourcing in manufacturing rather than service sector. Therefore, when systemising scholarly works on service sector, the point of view of the authors that categorise environmental factors, which influence the implementation of outsourcing and the goals of service companies, have been taken into account.

Lam, Han (2005) analysed hotel services and distinguished 9 factors, such as: reduction of cost, flexibility, pursuit of new technologies, pursuit of external knowledge and experience, added value for the image of service provider, optimisation of resources, increased income, entering new markets. Seeking to remain objective during their research, the authors asked the experts of hotel services to fill in the list of factors that encouraged them to outsource. Wan, Yen-Lun Su (2010) determined seven factors that are most frequently used in literature and, in order to remain accurate, used focus groups of hotel managers to check if the factors that they have selected are significant. The authors believe that reduction of costs, concentration on main company activities, flexibility, pursuit of new technologies, pursuit of external knowledge and experience, avoidance of capital investments and simplification of managerial work influence the implementation of outsourcing. Smuts et al. (2010) conducted research in communication service sector and distinguished eight factors encouraging the implementation of outsourcing: reduction of cost, flexibility, pursuit of new technologies, pursuit of external knowledge and experience, optimisation of resources, simplification of managerial work, improvement of money flows, reduction of the number of personnel. The research conducted by Lamminaki (2011) was based on scholarly theories and distinguished ten most significant factors, such as: reduction of costs, flexibility, specialisation of service provider, reduction or sharing of risk, example of competitors, avoidance of capital investment, opportunity for rapid establishment or expansion, management of volatility and unpredictability, unpredictable activities, broad scope of activities. When analysing bank services Jain, Natarjan (2011) concluded a list of outsourcing factors 
The International Journal

ENTREPRENEURSHIP AND SUSTAINABILITY ISSUES

ISSN 2345-0282 (online) http://jssidoi.org/jesi/

2018 Volume 6 Number 1 (September)

http://doi.org/10.9770/jesi.2018.6.1(21)

which was discussed with experts including senior bank managers, scholars and outsourcing service providers. The key factors are the following: reduction of costs, concentration on main company activities, flexibility, quality improvement, pursuit of new technologies, pursuit of external knowledge and experience, reduction or sharing of risk, control of costs, pursuit to improve the effectiveness of activity, the replacement of fixed costs by variable costs, simplification of managerial work.

Table 1. The determinants of the outsourcing factors

\begin{tabular}{|c|c|c|c|c|c|c|c|c|c|c|c|c|c|c|c|c|c|c|c|c|c|c|c|c|c|c|c|}
\hline & \multicolumn{27}{|c|}{ Factor determinants } \\
\hline Author, field of research & 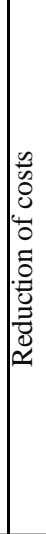 & 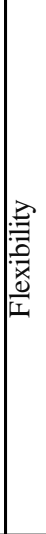 & 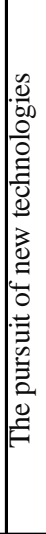 & 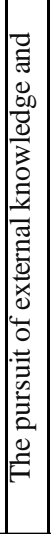 & 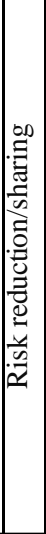 & 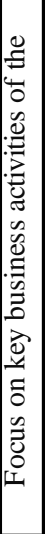 & 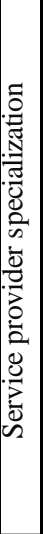 & 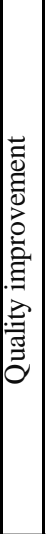 & 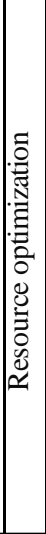 & 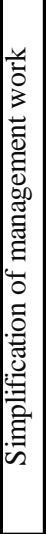 & 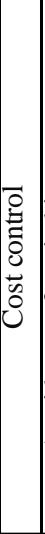 & 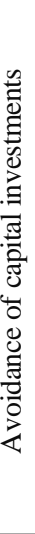 & 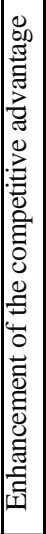 & 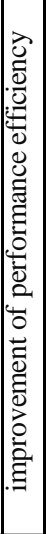 & 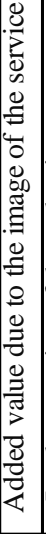 & 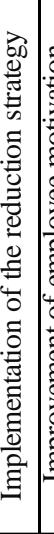 & 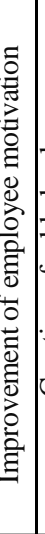 & 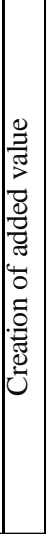 & 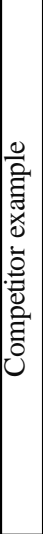 & 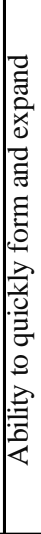 & 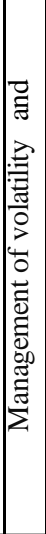 & 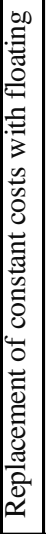 & 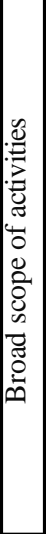 & 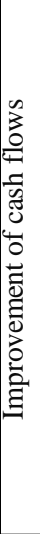 & 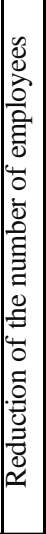 & 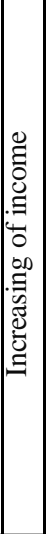 & 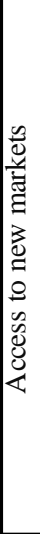 \\
\hline Borodako et al. (2015), organization of meetings & + & + & + & + & + & + & + & + & & & + & & + & + & & & + & + & & & & & & & & & \\
\hline Bay tok et al. (2013), hotels & + & + & + & & + & + & + & + & + & & & & + & & + & + & & & & & & & & & & & \\
\hline Lamminaki (2011), hotels & + & + & & & + & & + & & & & & + & & & & & & & + & + & + & & + & & & & \\
\hline Jain, Natarjan (2011), banks & + & + & + & + & + & + & & + & & + & + & & & + & & & & & & & & + & & & & & \\
\hline Wan, Yen-Lun Su (2010), hotels & + & + & & + & & + & + & & & + & & + & & & & & & & & & & & & & & & \\
\hline Smuts et al. (2010), communication services & + & + & + & + & & & & & + & + & & & & & & & & & & & & & & + & + & & \\
\hline Lam, Han (2005), hotels & + & + & + & + & + & & & & + & & & & & & + & & & & & & & & & & & + & + \\
\hline
\end{tabular}

The table shows that within the period of ten years the authors have usually analysed hotel services. However, irrespective of the services, all the authors determined that first of all, companies were encouraged to practice outsourcing by the reduction of costs and flexibility. Although researchers have analysed different services, 7-13 factors prevail and the total of 27 factors, which are classified as internal company factors, is provided in the matrix. The authors of this article believe that previously presented theoretical outsourcing concepts remain important when analysing and improving the results of service company activity as well as making decisions. Based on the foregoing, the link between the groups of the distinguished theoretical concepts and factors that influence the change of company activities can be observed. The first group consists of the factors which have been determined by conducting scholarly research and which are related to economic indicators: reduction of costs, flexibility, pursuit of new technologies, pursuit of knowledge and experience, reduction and sharing of risk. The factors in the second group are related to the main activity of the company and its management: concentration on main company activities, specialisation of service provider, quality improvement, optimisation of resources, simplification of managerial work. The third group includes such factors which have been distinguished only in the conducted research. Scientific works of other scholars on outsourcing of services were systemised in accordance with the researchers' point of view to external determinants and their components. Such researchers on service sector as Espino-Rodriguez, Ramirez-Fierro (2017), Ikediashi, Okwuashi (2015) Assaf et al., (2011), Gewald, Dibbern (2009) used all the factors determined in the research and attempted to systemise and group them accordingly (refer to Table 2). When analysing the aspects of outsourcing in bank sector with IT-related 
services, Gewald, Dibbern (2009) emphasised eight factors that influence the implementation of outsourcing and grouped them into: cost-related, main activity-related, related to the need for specialised resources and improvement of quality.

Table 2. The purpose of outsourcing factors

\begin{tabular}{|c|c|c|}
\hline $\begin{array}{l}\text { Author, } \\
\text { services }\end{array}$ & Factor groups & Purpose \\
\hline \multirow{2}{*}{$\begin{array}{l}\text { Espino-Rodriguez, } \\
\text { Ramirez-Fierro } \\
\quad(2017) \\
\text { Hotel services }\end{array}$} & Tactical & $\begin{array}{l}\text { To work more efficiently, meet the need for staff that urgently occurred, reduce costs, increase } \\
\text { profitability. }\end{array}$ \\
\hline & Strategic & $\begin{array}{l}\text { Management has more time to perform tasks, can better perform tasks, company employees can } \\
\text { perform more tasks, the organization can concentrate on core activities, more works are completed } \\
\text { with less effort, a possibility to have high qualification employees with a lot of experience presents, } \\
\text { provides a possibility to have more time which is allocated for other jobs, provides a possibility to } \\
\text { improve services. }\end{array}$ \\
\hline \multirow{6}{*}{$\begin{array}{l}\text { Ikediashi, Okwuashi } \\
\qquad \begin{array}{l}\text { (2015) } \\
\text { Health care and } \\
\text { social service }\end{array}\end{array}$} & Economic & $\begin{array}{l}\text { To reduce costs, reduce capital investment, reduce costs for non-core activities, take advantage of the } \\
\text { outsourcing provider cost effectiveness system, reduce costs by increasing performance. }\end{array}$ \\
\hline & Strategic & $\begin{array}{l}\text { To focus on key activities, improve strategic positions, increase flexibility, diversify resources, manage } \\
\text { demand fluctuations more efficiently, compare internal results with others, play with privatization } \\
\text { trend, share risk, and limit the number of employees. }\end{array}$ \\
\hline & Innovations & $\begin{array}{l}\text { To get access to new products and services, gain skills, experience and ideas, gain technology that is } \\
\text { not available in the company, react faster to new needs. }\end{array}$ \\
\hline & Quality & To improve productivity standards, improve service quality, and improve mutual trust with customers. \\
\hline & Temporal & To improve timely provision of services. Lack of time to buy tools and equipment. \\
\hline & Social & $\begin{array}{l}\text { To increase shareholder satisfaction, improve customer relations, improve employment relations, } \\
\text { improve social responsibility of the company }(S R C) \text {, create jobs for the local community. }\end{array}$ \\
\hline \multirow{6}{*}{$\begin{array}{l}\text { Assaf et al. (2011) } \\
\text { Educational services }\end{array}$} & Economic & $\begin{array}{l}\text { To reduce total costs, replace fixed costs with floating ones, improve cash flows, infusion of money, } \\
\text { make capital funds more accessible to core activities, and increase economic effectiveness. }\end{array}$ \\
\hline & Strategic & $\begin{array}{l}\text { Focus on the core activities, acquiring of global capabilities, freeing of resources for the core } \\
\text { activities, sharing the risk with the service provider, lack of internal resources, to improve the } \\
\text { flexibility, adapt to dynamic market changes, strategic alliances with the service provider, regulations } \\
\text { governing outsourcing practice. }\end{array}$ \\
\hline & Technological & $\begin{array}{l}\text { To gain flexibility with changing technologies, initiate innovative ideas and techniques, uncertainty of } \\
\text { technology demand, the need for specific experience, the aim to acquire new skills or technological } \\
\text { knowledge. }\end{array}$ \\
\hline & Quality & $\begin{array}{l}\text { To improve the quality of services, improve quality requirements, gaining of a competitive advantage } \\
\text { by improving service quality, the improvement of trust and competence. }\end{array}$ \\
\hline & Management & $\begin{array}{l}\text { To save time intended for management, reduce management workload, the need for specialized } \\
\text { management, increased implementation speed, functions with that are difficult to manage, } \\
\text { consolidation and decentralization. }\end{array}$ \\
\hline & $\begin{array}{l}\text { Functional } \\
\text { Characteristics }\end{array}$ & Complexity of functions, function integration and structure. \\
\hline \multirow{4}{*}{$\begin{array}{l}\text { Gewald, Dibbec } \\
\qquad(2009) \\
\text { Financial services }\end{array}$} & Costs & $\begin{array}{l}\text { Reduction of costs, optimizing of costs intended for performance-related programming, replacement } \\
\text { of fixed costs with floating ones }\end{array}$ \\
\hline & Core activities & $\begin{array}{l}\text { Separation of the performance of non-core activities, redirection of management focus at the core } \\
\text { activities, redirection of technical systems at core activities. }\end{array}$ \\
\hline & Specialized resources & The pursuit of knowledge and skills of professionals, access to better IT systems. \\
\hline & $\begin{array}{l}\text { Quality } \\
\text { Improvement }\end{array}$ & $\begin{array}{l}\text { To improve process monitoring and improvement, to reduce the probability of malfunctions and } \\
\text { errors. }\end{array}$ \\
\hline
\end{tabular}


The International Journal

ENTREPRENEURSHIP AND SUSTAINABILITY ISSUES

ISSN 2345-0282 (online) http://jssidoi.org/jesi/

2018 Volume 6 Number 1 (September)

http://doi.org/10.9770/jesi.2018.6.1(21)

When analysing the application of outsourcing in universities Assaf et al. (2011) identified 38 factors that influence the application of outsourcing and divided them into the following groups: economic, strategic, technological, quality, management, and function characteristics. Strategic factors enable the organisation to receive greater benefits related to the long-term goals of the company. Management factors encompass all the factors that influence the results of service activities and management and are related to the stages of product creation, control and implementation. Economic factors are related to the generation of profit, since outsourcing enables organisations to create the services cheaper than their competitors. Technological factors concern the acquisition of skills, technology, processes and methods, while quality factors deal with the satisfaction of customers' needs and improvement of product quality. Function characteristics factors include functions that should be carried out externally (Assaf et al. 2011). In the later studies, the above-mentioned factor groups have been invoked by other researchers on service sector: Gbadegesin, Babatunde (2015) researched universities, Suweero, Moungnoi, Charoenngam (2017) studied commercial sector and building maintenance services. Scholars Suweero, Moungnoi, Charoenngam (2017) used six groups of outsourcing factors which have been described by Assaf et al. (2011) and added the factors that are specific to the building maintenance services, thus concluding a list consisting of 56 components.

Ikediashi, Okwuashi (2015), who studied patient services in healthcare system, concluded a list of 65 components that influence the implementation outsourcing and divided them into eight groups: cost/economic, strategic, innovation, income, quality, time, social, other. Having conducted a pilot test in hospitals, the scholars shortened the list to 31 components and divided them into 5 groups: cost/economic, strategic, innovation, quality, time and social.

When conducting their research related to outsourcing in hotels and having analysed the works of other scholars as well as outsourcing factors used in prior empirical researches, Espino-Rodriguez, Ramirez-Fierro (2017) distinguished two groups, i.e. tactical and strategic, which consist of 12 factors.

Table 2 provides the goals that hotels, healthcare and social service, education and finance service companies pursue by practicing outsourcing. The data show that different services and their characteristics determined different factor groups and company goals. It should be noted that in the majority of cases the service providers related to the public wellbeing and the improvement of people's quality of life, such as healthcare, social service and education service providers aim at improving their activities. The majority of goals of such services coincide and are economic, strategic, innovation and quality, which are oriented towards the decision-making levels of service companies and related to the improvement of activities. The authors' research results show that the goals of all service companies include internal factors and only education companies aim at their development and reaching of goals, which are oriented towards external environment and are related to the integration of functions, adaptation to the changing market and acquisition of international capacity.

The empirical research carried out by other scholars can be categorised based on Assaf et al. (2011) methodology (Table 3), thus revealing the most significant factors that influence outsourcing. It can be observed that the most significant groups among service companies are strategic and economic factor groups. However, the claim of Arias-Aranda et al. (2010) that outsourcing should be viewed as a means of flexibility, the benefit of which is seen in the long term, rather than the means of cost reduction, whose benefit is observed in the short term, is to be taken into account.

Table 3. The components of factors that influence the implementation of outsourcing on services 
The International Journal

ENTREPRENEURSHIP AND SUSTAINABILITY ISSUES

ISSN 2345-0282 (online) http://jssidoi.org/jesi/

2018 Volume 6 Number 1 (September)

http://doi.org/10.9770/jesi.2018.6.1(21)

\begin{tabular}{|c|c|c|c|c|c|}
\hline \multirow{2}{*}{$\begin{array}{l}\text { Author, field of } \\
\text { research }\end{array}$} & \multicolumn{5}{|c|}{ Factors } \\
\hline & Economic & Strategic & Technological & Quality & Management \\
\hline $\begin{array}{l}\text { Espino-Rodriguez, } \\
\text { Ramirez-Fierro (2017), } \\
\text { hotels }\end{array}$ & $\begin{array}{l}\text { Cost reduction, increase of } \\
\text { profitability }\end{array}$ & $\begin{array}{l}\text { Efficiency, unexpected need } \\
\text { of personnel }\end{array}$ & & & \\
\hline $\begin{array}{l}\text { Borodako et al,. (2015), } \\
\text { organizers of business } \\
\text { meetings }\end{array}$ & & Efficiency, flexibility & & Quality improvement & \\
\hline $\begin{array}{l}\text { Ikediashi, Okwuashi } \\
\text { (2015), hospitals }\end{array}$ & & & & $\begin{array}{l}\text { Improving of performance } \\
\text { standards and service } \\
\text { quality }\end{array}$ & $\begin{array}{l}\text { Ensurance of a timely } \\
\text { service provision }\end{array}$ \\
\hline $\begin{array}{l}\text { Yildiz, Damire (2014), } \\
\text { hotels }\end{array}$ & $\begin{array}{l}\text { Reduction of general and } \\
\text { employee-related costs }\end{array}$ & $\begin{array}{l}\text { Investment risk reduction } \\
\text { and flexibility }\end{array}$ & & & \\
\hline $\begin{array}{l}\text { Sani A. et al. (2013), } \\
\text { hotels }\end{array}$ & $\begin{array}{l}\text { Reduction of operational } \\
\text { costs }\end{array}$ & $\begin{array}{l}\text { Internal resource } \\
\text { optimization, Reputation } \\
\text { of outsourcing provider }\end{array}$ & $\begin{array}{l}\text { Experience of outsourcing } \\
\text { provider }\end{array}$ & & \\
\hline $\begin{array}{l}\text { Bay tok et al. (2013), } \\
\text { hotels }\end{array}$ & Reduction of costs & & $\begin{array}{l}\text { The pursuit of new } \\
\text { technologies, service } \\
\text { provider specialization }\end{array}$ & Quality improvement & \\
\hline $\begin{array}{l}\text { Lamminaki (2011), } \\
\text { hotels }\end{array}$ & $\begin{array}{l}\text { Reduction of costs, } \\
\text { avoiding of capital } \\
\text { investments }\end{array}$ & \begin{tabular}{|l} 
Flexibility, ability to \\
quickly form and expand
\end{tabular} & & & \\
\hline $\begin{array}{l}\text { Assaf et al. (2011), } \\
\text { educational services }\end{array}$ & & Risk Sharing & & $\begin{array}{l}\text { Improvement of quality } \\
\text { requirements }\end{array}$ & $\begin{array}{l}\text { Reduction of } \\
\text { implementation time }\end{array}$ \\
\hline $\begin{array}{l}\text { Jain, Natarjan (2011), } \\
\text { banks }\end{array}$ & & $\begin{array}{l}\text { Importance of core } \\
\text { competencies }\end{array}$ & $\begin{array}{l}\text { Access to new skills and } \\
\text { new technologies }\end{array}$ & Focus on customer service & \\
\hline $\begin{array}{l}\text { Smuts et al. (2010), } \\
\text { communication services }\end{array}$ & Reduction of costs & $\begin{array}{l}\text { Flexibility, better resource } \\
\text { compatibility with the } \\
\text { needs }\end{array}$ & $\begin{array}{l}\text { Better access / to more } \\
\text { resources }\end{array}$ & & \\
\hline $\begin{array}{l}\text { Gewald, Dibbern } \\
\text { (2009), banks }\end{array}$ & Cost optimization & & & $\begin{array}{l}\text { Process monitoring and } \\
\text { improvement, error } \\
\text { reduction }\end{array}$ & $\begin{array}{l}\text { Improvement of the } \\
\text { management of core } \\
\text { activities }\end{array}$ \\
\hline Lam, Han (2005), hotels & $\begin{array}{l}\text { Cost reduction, increase of } \\
\text { income }\end{array}$ & $\begin{array}{l}\text { Risk reduction, resource } \\
\text { optimization }\end{array}$ & & & \\
\hline
\end{tabular}

Source: authors

Sani et al. (2013) applied outsourcing models of hotel services and complemented this point of view by claiming that outsourcing allows improving the quality of outsourced activities, as they are carried out by companies specialising in specific activities, while hotels are able to concentrate on their main activities thus improving their quality. The table shows that the majority of empirical researches have been conducted in hotels, which is determined by the fact that the scope of tourism-related services is growing. An important position of the researched fields is assumed by the service quality, prompted not only by an increasing amount of attention to customers, but also by service quality requirements. Scientific research revealed that economic and strategic factors dominated among the most significant factors encouraging outsourcing in service companies. 
The International Journal

ENTREPRENEURSHIP AND SUSTAINABILITY ISSUES

ISSN 2345-0282 (online) http://jssidoi.org/jesi/

2018 Volume 6 Number 1 (September)

http://doi.org/10.9770/jesi.2018.6.1(21)

The analysis showed that the development of outsourcing is affected by both environmental changes that are independent from the organisation and internal decisions related to the activity of the organisation and its improvement. When analysing scholarly research, it can be observed that scholars analyse the internal factors that influence the development of outsourcing in two ways: by emphasising the factors that are most frequently found in the literature and by attempting to encompass all the factors that were found and dividing them into separate groups. Since scholarly literature does not exclude the factors that are specific to outsourcing in service companies, researches conducted in separate service company groups have been analysed. Having conducted this analysis, the conclusion has been reached that strategic and economic factors influence the development of outsourcing of services the most.

\section{Conclusions}

The change and development of outsourcing has been defined in scholarly literature by employing a variety of scientific theories, which aim at finding the basis of outsourcing and its development factors. Provided theories were divided into three groups: theories related to economic and cost reduction decisions of the companies, theories related to strategic management and theories related to collaboration and development decisions. Transaction cost theory, resource-based view theory, research dependency theory and the theories belonging to the third group can be considered the most significant and applicable theories in the context of the future researches on outsourcing. It is noteworthy that the significance of the third theory group is increasing as transaction cost theory, resource-based view theory and research dependency theory are used as a basis of outsourcing, however, the latest research shows that outsourcing has underwent development and transformation (related to restructuring and partnership). Therefore, the third theory group serves as a basis of outsourcing development factors at certain levels of collaboration. Theoretical concepts related to the expectations of service providers and receivers, change of service quality and use, will continue to be modelled and verified alongside classical innovation diffusion theory.

Although service sector researches emphasise that cost reduction should not be considered the key reason of outsourcing, while based on the results of empirical researches economic factors prevail, we believe that the scope of outsourcing will increase, while the service quality parameters will become the most important when expanding the activities of companies and striving for competitive advantage.

The benefit and growth of service outsourcing is unquestioned. Although the determined groups of outsourcing factors are sufficiently clear, a varying and large number of components (up to 65) burdens the identification of general and specific tendencies of outsourcing development. Furthermore, assessment and comparison of outsourcing among different countries and regions is not possible due to the limited spread of empirical researches (covering only a few service groups according to the WTO) and its results. Therefore, further research in this direction would be useful.

\section{References}

Alajaasko P. 2006. The demand for services: external but local provision, Statistics in focus: industry, trade and services, 26: 1-8. http://ec.europa.eu/eurostat/documents/3433488/5443985/KS-NP-06-026-EN.PDF/5bbca935-d765-42b4-9533-edc36bcccee7?version=1.0

Arias-Arand D., Bustinza O.F., Barrales-Molina V. (2011). Operations flexibility and outsourcing benefits: an empirical study in service firms, The service industries journal, Vol. 31, No. 11, 1849-1867. https://doi.org/10.1080/02642069.2010.503880

Assaf S. et al. 2011. Factors affecting outsourcing decisions of maintenance services in Saudi Arabian universities, Property management, Vol. 29, No. 2, 195-212. https://doi.org/10.1108/02637471111122471 


\section{The International Journal}

ENTREPRENEURSHIP AND SUSTAINABILITY ISSUES

ISSN 2345-0282 (online) http://jssidoi.org/jesi/ 2018 Volume 6 Number 1 (September)

http://doi.org/10.9770/jesi.2018.6.1(21)

Aubert B. A., Rivard S., Patry M. 1996. A transaction cost approach to outsourcing behavior: Some empirical evidence, Information \& Management, Vol. 30, No.2, 51-64. https://doi.org/10.1016/0378-7206(95)00045-3

Bahrami B. 2009. A look at outsoutcing offshore, Competitivess Rewiev: An International business Journal, Vol. 19, No. 3, $212-223$. https://doi.org/10.1108/10595420910962089

Baytok et al. 2013. Outsourcing in Thermal Hotel Enterprises: The Case of Turkey, Business Management Dynamics, Vol.3, No.5, 01-14. http://bmdynamics.com/issue_pdf/bmd110425-\%2001-14.pdf

Blumberg D. F. 1998. Strategic assessment of outsourcing and downsizing in the service market, Managing service quality, Vol. 8., No 1., 5-18. https://doi.org/10.1108/09604529810199340

Borodako et al. 2015. External and Internal Factors Motivating Outsourcing of Business Services by Meeting-Industry Companies: A Case Study in Krakow, Poland, Journal of Convention \& Event Tourism, 16:93-115. https://doi.org/10.1080/15470148.2015.1013170

Busi M., McIvor R. 2008. Setting the outsourcing research agenda:the top-10 most ugent outsourcing areas, Strategic outsourcing: An international journal, Vol.1, No. 3, 185-197. https://doi.org/10.1108/17538290810915263

Dibbern J., Hirschheim R. 2004. Information systems outsourcing: A survey and analysis of the literature. Data Base for Advances in Information Systems, Vol. 35, No. 4, 6-102.

https://www.researchgate.net/publication/220627990_Information_systems_outsourcing_A_survey_and_analysis_of_the_literature

Espino-Rodríguez T. F., Ramírez-Fierro J.C. 2017. Factors determining hotel activity outsourcing. An approach based on competitive advantage. International Journal of Contemporary Hospitality Management, Vol. $29 \quad$ Issue: 8, $2006-2026$. https://doi.org/10.1108/IJCHM-05-2016-0291

Franchesi F. et al. 2003. Outsourcing: guidelines for a structured approach, Benchmarking: An international journal, Vol. 10, No. 3, 246260. https://doi.org/10.1108/14635770310477771

Fuschi, D. L.: Tvaronavičienè, M. 2016. A network based business partnership model for SMEs management, Entrepreneurship and Sustainability Issues 3(3): 282-289. https://doi.org/10.9770/jesi.2016.3.3(5)

Gbadegesin J. T., Babatunde T. O. 2015. Investigating expert's opinion on outsourcing decision in facilities management practice in public univercities in Nigeria. Journal of facilities management, Vol. 13, No.1, 27-41.

Gerbl M., McIvor R., Humphrey 2009. Global services outsourcing: Critical aspects and future directions. POMS 20th Annual Conference, 1-23. https://pomsmeetings.org/ConfProceedings/011/FullPapers/011-0518.pdf

Gewald H., Dibbern J. 2009. Risks and benefits of business process outsourcing: A study of transaction services in the German banking industry. Information \& Management, 46, 249-257. https://doi.org/10.1016/j.im.2009.03.002

Gomez J. F. et al. 2009. Outsourcing maintanance in service providers, Taylor \&Francis group,, 829-837. https://pdfs.semanticscholar.org/d73f/8b4a2f653acf96aa3dab9015be1e0ea7688b.pdf

Gottschalk, P., Solli-Sæther H. 2006. Maturity model for IT outsourcing relationships, Industrial Management and Data Systems, 106 (2), 200-212. https://doi.org/10.1108/02635570610649853

Ikediashi D., Okwuasi O. 2015. Significant factors influencing outsourcing decision for facilities management (FM) services: A study of Nigeria's public hospitals. Property management, Vol. 33 Iss1, 59-82. https://doi.org/10.1108/PM-04-2014-0018

Yi S., Guo K., Chen Z. 2016. Forecasting China's service outsourcing development with an EMD-VAR-SVR ensemble method. Procedia computer science, 91, 392-401. https://doi.org/10.1016/j.procs.2016.07.101

Jain R.K., Natarjan R. 2011. Factors influencing the outsourcing decisions: a study of the banking sector in India, Strategic Outsourcing: An International Journal, Vol. 4 No. 3, 294-322. https://doi.org/10.1108/17538291111185485

Kishore R. et al. A. 2003. A relationship perspective on IT outsouring, Communications of the ACM, Vol.46, No.12, 86-92. https://www.researchgate.net/publication/234779357 A relationship perspective on IT outsourcing 
Kedia B.L., Lahiri S. 2011. Co-evolution of institutional and organizational factors in explaining offshore outsourcing, International business review, 20, 252-263. https://doi.org/10.1016/j.ibusrev.2011.01.005

Kedia B.L., Mukherjee D. 2009. Understanding offshoring: A research framework based on disintegration, location, and externalization advantages, Journal of World Business, 44, 250-261. https://doi.org/10.1016/j.jwb.2008.08.005

Koszewska M. 2004. Outsourcing as a modern management strategy. Prospects for its development in the prospective clothing market, Autex Research magazifoone, Vol. 4, No.4, 228-231. http://www.autexrj.com/cms/zalaczone_pliki/8-04-4.pdf

Kremic T., Tukel O. I., Rom W. O. 2006. Outsourcing decision support: a survey of benefits, risks and decision factors, Supply chain management: An international journal, 11/6, 467-482. https://doi.org/10.1108/13598540610703864

Lankford W. M., Parsa F. (1999). Outsourcing: a prime, Management decision, 37/4, 310-316.

Lam T., Han M.X.J. 2005. A study of outsourcing strategy: a case involving the hotel industry in Shanghai, China. Hospitality Management, Vol. 24, 41-56. https://doi.org/10.1016/j.ijhm.2004.04.002

Lamminmaki D. 2011. An examination of factors motivating hotel outsourcing. International Journal of Hospitality Management, 30, 963973. https://doi.org/10.1016/i.ijhm.2010.10.010

Mclvor R. (2005). The Outsourcing Process - Strategies for Evaluation and Management. - UK: Cambridge University Press, 224.

Mickeviciene M. Imonés gebejimo konkuruoti tyrimo metodologija. Daktaro disertacija, KTU, Kaunas 2010

Michael L. Tushman M.L. 1977. A Political Approach to Organizations: A Review and Rationale, The Academy of Management Review Vol. 2, No. 2, 206-216. https://www.jstor.org/stable/257904?seq=1\#page_scan_tab_contents

Pauceanu, A. M. 2016. Innovation and entrepreneurship in Sultanate of Oman - an empirical study, Entrepreneurship and Sustainability Issues 4(1): 83-99. https://www.researchgate.net/publication/286449154_Innovation_and_entrepreneurship_in_Sultanate_of_Oman_an empirical study

Perunovic Z., Pedersen J.L. 2007. Outsourcing Process and Theories, POMS 18th Annual Conference Dallas, Texas, U.S.A., https://www.researchgate.net/publication/252405855 Outsourcing Process and Theories

Rogers, E. M. (1962). Diffusion of innovations. First edition. New York. Free Press. ISBN 0612628434.

Sakas, D., Kutsikos, K. 2013. An Adaptable Decision Making Model for Sustainable Enterprise Interoperability, 2nd International Conference on Strategic Innovative Marketing. https://doi.org/10.1016/j.sbspro.2014.07.087

Sani A., Dezdar S., Ainin S. 2013. Outsourcing patterns among Malaisian hotels, International juornal of business and social science, Vol.4, No. 9.,113-114. http://www.ijbssnet.com/journals/Vol_4_No_9_August_2013/13.pdf

Smuts H. et al. (2010). Information systems outsourcing issues in the communication technology sector. IADIS International Conference Information Systems, 145-155. http://hdl.handle.net/10204/4160

Suweero K., Moungnoi W., Charoenngam Ch. 2017. Outsourcing decision factors of building operation and maintenance services in the commercial sector, Property Management, Vol. 35 Issue: 3, 254-274. https://doi.org/10.1108/PM-06-2016-0028

Tushman M.L.1977. A Political Approach to Organizations: A Review and Rationale. The Academy of Management Review Vol. 2, No. 2, 206-216. http://www.jstor.org/stable/257904

Vaxevanou A., Konstantopouls N. 2015. Models referring to outsourcing theory. Procedia - Social and Behavioral Sciences, Vol. 175, 572 - 578. https://doi.org/10.1016/j.sbspro.2015.01.1239

Wan C-S., Yen-Lun Su A. 2010. Exploring the Factors Affecting Hotel Outsourcing in Taiwan, Asia Pacific Journal of Tourism Research, Vol. 15, No. 1., 95-107. https://doi.org/10.1080/10941660903510099 
The International Journal

ENTREPRENEURSHIP AND SUSTAINABILITY ISSUES

ISSN 2345-0282 (online) http://jssidoi.org/jesi/

2018 Volume 6 Number 1 (September)

http://doi.org/10.9770/jesi.2018.6.1(21)

Yanhong W. 2011. A Framework of Business Process Outsourcing Relationship Evolution Model, Management Science and Industrial Engineering (MSIE), International Conference. 10.1109/MSIE.2011.5707581

Yildiz S., Damire Z. H. 2014. The benefits, risks and effects on performance of the outsourcing: A comparative study of seasonal and permanent hotels. Procedia - Social and Behavioral Science, Vol. 109, 514-521. https://doi.org/10.1016/j.sbspro.2013.12.499

Zhu Z., Hsu K., Liulie J. 2001. Outsourcing - a strategic move: the process and the ingredients for success, Managing decision, 39/5, 373378. https://doi.org/10.1108/EUM0000000005473

World investment report:the shift toward services//United Nations Commission on Trade and Development 2004 http://unctad.org/en/docs/wir2004_en.pdf

The role of the services economy and trade in structural transformation and inclusive development // Trade and Development Board Trade and Development Commission Multi-year Expert Meeting on Trade, Services and Development Fifth session Geneva, 18-20 July 2017 Item 3 of the provisional agenda http://unctad.org/meetings/en/SessionalDocuments/c1mem4d14 en.pdf

Rima ZITKIENE is the Professor of Social Sciences (Management) at Mykolas Romeris University, Economics and Business Faculty, Lithuania. She has published over 60 articles in Lithuanian and foreign scientific journals, monographs, research studies and textbooks. Since 2007 she is expert on the database of humanities and social sciences of the Lithuanian Academy of Sciences "Lituanistika"; since 2010 expert of EDAMBA ('European Doctoral programs Association in Management \& Business Administration) and EIASM (European Institute for Advanced Studies in Management); member of ERA (European Retail Academy); since 2010 a member of Doctoral Committee studies in Management Science (Consortium - Vytautas Magnus University together with Lithuanian University of Agriculture, Klaipeda University, Mykolas Romeris University, Siauliai University). Her research interests are in a field of retailing, service and business management.

ORCHID ID: https://orcid.org/0000-0002-0954-7251

Ugne DUDE Phd candidate of Management Sciences. Research interests: business management, outsourcing, marketing, international trade, services.

ORCID ID: https://orcid.org/0000-0002-6319-7045

Copyright (C) 2018 by author(s) and VsI Entrepreneurship and Sustainability Center

This work is licensed under the Creative Commons Attribution International License (CC BY).

http://creativecommons.org/licenses/by/4.0/

C) (i) Open Access 